ISSN 1979-5572 (print)

ISSN 2541-6480 (online

http://ejurnal.iainpare.ac.id/index.php/kuriositas

\title{
KURIOSITAS
}

Media Komunikasi Sosial dan Keagamaan

\begin{tabular}{lll}
\hline Volume 11 & No. 2, Desember 2018 & Halaman 135-144 \\
\hline
\end{tabular}

\section{STUDENT TEAM ACHIEVMENT DIVISION DALAM MENINGKATKAN HASIL BELAJAR SISWA}

\author{
Muhammad Jufri \\ SMK 01 Parepare \\ muhammadjufrismk01@gmail.com
}

\begin{abstract}
The importance of this research was the essence of learning trough student team achievement division and the implementation steps that have not been done on the research object. The level of learning was decided by students that still need to be maximized to achieve the minimum completion criteria established by the school. The objective of the research is to know the form of implementation and effetiveness of learning trough Student Team Achievement Division in improving the outcomes (result) of learning lslamic Religion Education for the eleventh grade on SMK Negeri 1 Parepare. The research setting used in this research was a classroom action research which was conducted cyclically with experimental approach. The subjects of this research are the eleventh grade on SMK Negeri 1 Parepare and the numbers of the subjects were 25 student. The method of data collection as research instrument was tes, participant observation sheet, and documentation, the data analysis technique used.frequency distribution analysis. The research result found that Student Team Achievement Division (STAD) as learning strategy was effetive to improve the students learning outcomes of the eleventh grade of SMK Negeri I Parepare.

Keyword : Effectiveness, Learning, Student Team Achievment Division, Learning Outcomes

ABSTRAK

Tujuan penelitian ini adalah untuk mengetahui bentuk pelaksanaan dan efektivitas pembelajaran Student Team Achievment Division dalam meningkatkan hasil belajar Pendidikan Agama Islam kelas XI di SMK Negeri 1 Parepare. Metode penelitian yang pergunakan dalam penelitian ini adalah
\end{abstract}


penelitian tindakan kelas yang dilakukan secara bersiklus dengan pendekatan eksperimen. Subjek penelitian ini adalah peserta didik kelas XI di SMK Negeri 1 Parepare sebanyak 25 orang. Adapun metode pengumpulan data sebagai instrumen penelitian adalah tes, lembar observasi berpartisipatif, dan dokumentasi; sedangkan teknik analisis datanya mempergunakan analisis distribusi frekuensi. Dari penelitian ini kemudian ditemukan bahwa pembelajaran Student Team Achievment Division efektif dalam meningkatkan hasil pembelajaran Pendidikan Agama Islam di SMK Negeri 1 Parepare. Hasil penelitian ini dapat dijadikan sebagai bahan masukan dan khasanah intelektual dalam pendekatan pembelajaran.

Kata kunci : Efektivitas, Pembelajaran, Student Team Achievment Division, Hasil Belajar

\section{PENDAHULUAN}

Kegiatan pembelajaran di sekolah adalah interaksi antara pendidik dan peserta didik dalam mempelajari suatu materi pelajaran. Tujuan interaksi pembelajaran ini telah disusun dalam tujuan instruksional pada setiap pokok dan sub pokok materi pembelajaran.

Efektivitas pencapaian tujuan instruksional dalam bentuk peningkatan hasil pembelajaran peserta didik dapat dipengaruhi oleh dua faktor, yaitu faktor instrumental input dan environmental input. Pada faktor instrumental input dibagi atas faktor kurikulum, pendidik, model dan strategi pembelajaran, materi, waktu, dan biaya pendidikan. Sedangkan pada faktor environmental input adalah terdiri atas faktor lingkungan pendidikan, baik lingkungan keluarga, masyarakat, lingkungan sosial budaya, keamanan, politik dan lingkungan keagmaan.

Dalam penelitian ini, berfokus pada faktor instrumental input yaitu faktor pendidik dan model pembelajarannya dalam meningkatkan hasil belajar peserta didik. Penelitian ini sangat penting dilakukan, obeservasi awal penulis menunjukkan bahwa kurangnya penerapan model pembelajaran Student Team Achievment Division pada masing-masing sekolah di tingkat sekolah menengah dan sederajat sebagai salah satu modus ketidakefektifan proses pembelajaran di kelas. Sementara salah satu asumsi ideal tentang meningkatnya hasil belajar peserta didik adalah dengan penerapan model pembelajaran kooperatif. Dengan demikian, model pembelajaran Student Team Achievment Division penting untuk diteliti.

Pembelajaran Student Team Achievment Division (berarti kerjasama tim dan learning berarti pengetahuan atau pelajaran). Pembelajaran Student Team Achievment Division berhubungan dengan proses pembelajaran, maka istilah 
Student Team Achievment Division tersebut diartikan dengan pembelajaran tim kelompok yang bersifat kooperatif. Singkatnya pembelajaran Student Team Achievment Division mengacu pada metode pembelajaran di mana siswa bekerja sama dalam kelompok kecil dan saling membantu dalam belajar. (Huda 2011)

Pembelajaran cooperative tipe Student Team Achievment Division secara etimologi mempunyai arti belajar bersama antara dua orang atau lebih. Secara luas, pembelajaran cooperative tipe Student Team Achievment Division ini memiliki defenisi antara lain adalah belajar bersama yang melibatkan antara 4-6 orang yang bekerja sama menuju kelompok kerja di Alquran mana tiap anggota bertanggung jawab secara individu sebagai bagian dari hasil yang tak akan bisa dicapai tanpa adanya kerjasama antar kelompok. Dengan kata lain anggota kelompok saling tergantung secara positif (Mustamin 2009).

Model Student Team Achievment Division adalah suatu metode dalam pembelajaran kooperatif yang paling sederhana. Metode ini dikembangkan oleh Robert Slavin dan teman-temannya di Unversitas John Hopkin. Metode ini juga mengacu pada belajar kelompok siswa.(Sukardi 2013) Robert Slavin yang dikutip oleh Trianto menyatakan bahwa pada Student Team Achievment Division peserta didik ditempatkan dalam tim belajar beranggotakan 4-6 orang yang merupakan campuran menurut tingkat prestasi, jenis kelamin, dan suku. Guru menyajikan pelajaran, dan kemudian peserta didik bekerja dalam tim mereka memastikan bahwa seluruh anggota tim telah menguasai pelajaran tersebut. Kemudian, seluruh peserta didik diberikan tes tentang materi tersebut, pada saat tes ini mereka tidak diperbolehkan saling membantu.(Trianto and Pd 2009)

Student Team Achievment Division juga merupakan suatu model pembelajaran kooperatif yang efektif. Guru yang menggunakan Student Team Achievment Division juga mengacu pada belajar kelompok peserta didik. Menyajikan informasi akademik baru kepada peserta didik dan melaksanakan serta menggunakan presentasi verbal atau teks.(Cahyo 2013)

Fenomena strategi pembelajaran yang umum dipraktekkan di masingmasing sekolah khususnya pada objek penelitian ini adalah strategi dan konsep lama yaitu ceramah, tanya jawab, penugasan, resitasi, demonstrasi, dan lain-lain. Penerapan pembelajaran Student Team Achievment Division belum diterapkan khususnya pada bidang studi Pendidikan Agama Islam di SMK Negeri 1 Parepare. Metode Student Team Achievment Division tersebut pada prinsipnya telah dipraktekkan namun esensi dan langkah-langkah penerapannya belum dilakukan secara profesional. Dengan demikian, penelitian ini akan mencoba mengeksperimen tingkat efektivitas pembelajaran Student Team Achievment Division dalam meningkatkan hasil belajar peserta didik. 
Penerapan pembelajaran Student Team Achievment Division ini penting untuk mencapai tujuan pembelajaran atau tujuan instructional. Tujuan ini menyangkut pencapaian peningkatan hasil belajar peserta didik khususnya pada bidang studi Pendidikan Agama Islam di SMK Negeri 1 Parepare. Penerapan pembelajaran Student Team Achievment Division ini akan dilaksanakan dalam bentuk penelitian tindakan kelas sehingga dapat diperoleh hasil penelitian yang dapat direkomendasikan untuk dilaksanakan pada setiap tingkatan pendidikan. Dengan demikian, yang sangat urgen untuk diteliti adalah bagaimana efektivitas pembelajaran Student Team Achievment Division dalam peningkatan hasil belajar Pendidikan Agama Islam peserta didik kelas XI di SMK Negeri 1 Parepare.

\section{METODE}

Penelitian ini adalah penelitian tindakan kelas (classroom action research). Penelitian tindakan kelas bertujuan untuk meningkatkan kualitas proses, pendekatan strategi pembelajaran dan hasil belajar peserta didik. Penelitian ini meliputi langkah-langkah yaitu tahapan perencanaan (planning), pelaksanaan tindakan (acting), observasi (observing), dan refleksi (reflecting).

Penelitian tindakan kelas ini dilaksanakan pada semester 1 tahun pelajaran 2016-2017 yang terbagi atas dua atau tiga siklus. Apabila tahapan siklus dua belum mencapai peningkatan hasil pembelajaran yang signifikan, maka dapat dilanjutkan pada siklus tiga. Apabila siklus tiga juga belum mengalami peningkatan yang signifikan, maka penerapan model pembelajaran kooperatif tipe Student Team Achievment Devision dapat ditetapkan bahwa tidak efektif dalam peningkatan hasil pembelajaran Pendidikan Agama Islam khususnya di SMK Negeri 1 Parepare.

\section{PEMBAHASAN}

\section{Tahapan Pelaksanaan Pembelajaran Student Team Achievment Division}

Tahapan siklus yang ditempuh dalam pembelajaran Student Team Achievment Division, yaitu:

Peserta didik dibagi dalam kelompok kecil 4-6 secara heterogen menurut prestasi, jenis kelamin, ras, dan suku. Kemudian, guru menyampaikan tujuan, menyajikan bahan pelajaran, membimbing kelompok, dan memotivasi peserta didik. Selanjutnya, peserta didik diberi tes tentang materi yang telah diajarkan. Guru memberikan penghargaan untuk siswa.

Kelebihan model pembelajaran Student Team Achievment Devision sesuai dengan langkah-langkah di atas adalah untuk meningkatkan motivasi, kreativitas, dan prestasi belajar peserta didik. Pembelajaran ini dilakukan dengan berkelompok, sehingga peluang untuk mendengar, menerima, dan menghormati 
pendapat anggota kelompok lebih efektif. Tingkat kesadaran diri dan hubungan sosial lebih baik serta saling memahami dan saling mengerti antara peserta didik lebih diutamakan sehingga dapat mengurangi perasaan jenuh dan bosan dalam belajar.

Langkah yang ditempuh dalam penerapan model pembelajaran Student Team Achievmen Devision pada penelitian tindakan kelas adalah melakukan perencanaan untuk melakukan tindakan dengan menentukan pokok bahasan yang akan diajarkan. Pokok bahasan ini diawali dengan memberikan tes awal sebagai alat ukur untuk mengetahui tingkat pemahaman peserta didik terhadap materi tersebut. Pembagian kelompok tanpa melihat latar belakang peserta didik mutlak dilakukan dalam model pembelajaran kooperatif untuk memudahkan menyampaikan tujuan, menyajikan bahan pelajaran, membimbing kelompok, dan memotivasi peserta didik serta melakukan tes siklus untuk menentukan terjadinya peningkatan hasil belajar kemudian memberikan penghargaan.

Tes awal yang diberikan kepada peserta didik disesuaikan dengan pokok bahasan dan materi yang akan diajarkan pada pelaksanaan siklus. Hasil dari tes awal tersebut, dijadikan dasar pengukuran dan perbandingan terjadinya peningkatan atau penurunan hasil belajar peserta didik.

Peserta didik dibagi dalam kelompok kecil 4-6 secara heterogen menurut prestasi, jenis kelamin, ras, dan suku. Pada objek penelitian dilakukan pembagian kelompok menurut heterogenitas peserta didik dalam 5 orang dalam satu kelompok. Heterogenitas pada pencapaian nilai hasil belajar, jenis kelamin, ras, dan suku kesemuanya disatukan dalam satu kelompok latar belakang yang berbeda sehingga terjadi suasana kerjasama dan kebersamaan atas heterogenitas tersebut.

Guru menyampaikan tujuan, menyajikan bahan pelajaran, membimbing kelompok, dan memotivasi peserta didik. Pembelajaran Student Team Achievement Devision dilaksanakan dengan menyampaikan tujuan dengan standar kompetensi dan kompetensi dasar yang harus dicapai. Kompetensi tersebut diperoleh dari kurikulum yang disajikan ke dalam rencana program pembelajaran atau satuan acara pembelajaran. Setelah menyampaikan tujuan pembelajaran dilanjutkan dengan penyajian materi pelajaran secara singkat kemudian membagi dan membimbing kelompok yang telah dibentuk berdasarkan heterogenitas tadi sehingga proses tersebut dapat menimbulkan motivasi belajar pada peserta didik.

Sebelum pemberian tes siklus, guru membimbing terlebih dahulu dan menjelaskan materi pelajaran serta menyampaikan pokok-pokok masalah yang akan dibahas dengan menggunakan model pembelajaran Student Team Achievment Division. Hal ini, dimaksudkan agar peserta didik memahami betul 
pokok bahasan dan masalah yang akan didiskusikan pada materi pelajaran yang akan disampaikan.

Kehadiran guru dalam memberikan bimbingan sangat dibutuhkan agar peserta didik lebih fokus pada pokok masalah dan pembahasan. Salah satu bentuk bimbingan yang dilakukan adalah dengan menjelaskan lembar kerja siswa, membimbing peserta didik mengerjakan soal atas pertanyaan yang diberikan, memanggil peserta didik secara acak untuk menjawab atau menyelesaikan soal. Hal ini bertujuan supaya semua peserta didik selalu mempersiapkan diri sebaik mungkin, pemberian tugas kelas tidak boleh menyita waktu yang terlalu lama. Sebaiknya peserta didik mengerjakan satu atau dua masalah dan langsung diberikan umpan balik.

Pemberian materi pelajaran secara singkat pokok-pokok bahasan dan sub-sub pokok bahasan yang dilengkapi dengan lembar kerja siswa. Lembar kerja siswa dibagikan kepada masing-masing siswa pada setiap kelompok untuk dipelajari. Lembar kerja siswa ini diberikan kepada kelompok yang bertanggung jawab untuk mempersentasikan. Setelah persentasi kelompok, lalu dilanjutkan sesi diskusi dan tanya jawab. Semua peserta diskusi wajib memberikan tanggapan atau pertanyaan sehingga terjadi proses pembelajaran yang aktif dan kreatif.

Sebagai kegiatan inti dari model pembelajaran Student Teams Achievement Divisions, maka peneliti mempersiapkan materi yang akan diajarkan dalam poses pembelajaran di kelas yaitu tentang materi pelajaran Alquran dan rukun iman. Materi ini akan dijelaskan dalam bentuk garis-garis besar isi untuk memudahkan pemahaman inti materi tersebut. Pada penjelasan garis besar isi materi pelajaran, siswa belum fokus dan serius memperhatikan. Peneliti mencoba menarik perhatian siswa dengan memberikan pertanyaan-pertanyaan yang bertujuan agar siswa dapat tenang dan memperhatikan apa yang menjadi fokus pembahasan dalam pertemuan tersebut.

Peserta didik diberi tes tentang materi yang telah diajarkan setelah proses langkah-langkah pembelajaran. Pelaksanaan tes ini ditujukan untuk mengetahui keberhasilan proses instruksional yang telah dilaksanakan dengan penerapan pembelajaran Student Team Achievment Devision. Pemberian tes lisan tersebut rutin dilakukan setelah proses pembelajaran dengan penerapan Student Team Achievment Devision yaitu sebanyak tiga kali tes.

Pemberian tes selanjutnya dilakukan pada setiap akhir siklus yaitu pada pertemuan ke empat. Nilai yang diperoleh dari hasil tes akhir siklus dijadikan sebagai dasar dalam menentukan tingkat efektivitas pelaksanaan pembelajaran Student Team Achievment Devision yang dilakukan secara bersiklus. 
Proses pelaksanaan pembelajaran Student Team Achievment Division selanjutnya adalah memberikan penghargaan kelompok sesuai pencapaian nilai rata-rata kelompok tersebut yang tuntas dalam pencapaian Kriteria Ketuntasan Minimal. Kriteria penghargaan yang diberikan bagi kelompok dengan pencapaian Kriteria Ketuntasan Minimal pada kategori kurang baik, baik, hebat, dan super.

Langkah dalam model pembelajaran Student Team Achievement Devison tersebut dapat memberikan pemahaman bahwa peranan guru sangat penting untuk mengarahkan dan membimbing peserta didik, memberikan garis besar dan prosedur kegiatan, juga tata cara kerja kelompok yang akan dipelajari. Tentu seorang guru membentuk kelompok, membimbing, mengadakan kuis dan menilai peserta didik. pemberian nilai rata-rata peserta didik dan nilai rata-rata kelompok diperuntukkan untuk menentukan tingkat peningkatan hasil belajar dan memberikan penghargaan kelompok sehingga memungkinkan untuk melakukan reflecting dan membuat suatu simpulan hasil pelaksanaan siklus.

\section{Efektivitas model pembelajaran Student Team Achievment}

Efektivitas model pembelajaran Student Team Achievment Division dapat diketahui setelah melakukan penelitian dalam bentuk tindakan kelas. Berikut niali rata-rata siswa pada Pratindakan

$$
\begin{aligned}
\text { Mean } & =\frac{\sum \mathrm{X}}{\mathrm{N}} \mathrm{X} 100 \\
& =\frac{1760}{25} \times 100=70,4
\end{aligned}
$$

Data tersebut menunjukkan bahwa sebelum diberi perlakuan nilai rata-rata siswa hanya mencapai 70,4. Sehingga dianggap tidak mencapai KKM. Selanjutnya diterapkan model pembelajaran Student Team Achievment Division.

Berdasarkan data tersebut terlihat bahwa nilai siswa pada siklus II meningkat dari nilai rata-rata 85, 80 menjadi 95, 60. Peningkatan ini, menunjukkan bahwa siklus 2 berhasil, dan tidak perlu dilanjutkan ke siklus berikutnya.

Pelaksanaan Model Pembelajaran Student Team Achievment Devision dalam Meningkatkan Hasil Belajar Pendidikan Agama Islam

Model pembelajaran Student Team Achievment Devision dilaksanakan di kelas XI pada SMK Negeri I Parepare dengan jumlah 25 orang siswa. Tahapan dalam penelitian ini meliputi: tes awal dan pembentukan kelompok, belajar kelompok, tes akhir, perhitungan nilai skor, dan pemberian penghargaan/hadiah bagi nilai kelompok tertinggi. Sebelum proses pembelajaran, siswa dibagi dalam 
lima kelompok di mana setiap kelompok terdiri dari 5 orang siswa. Pembentukan kelompok dalam penelitian ini dilakukan oleh peneliti pada pertemuan pertama setelah mengetahui hasil tes awal. Hal ini dilakukan untuk menjamin anggota kelompok yang heterogen. Pemilihan kemampuan berdasarkan pada latar belakang dan skor tes awal siswa.

Pelaksanaan pembelajaran terdiri atas 2 siklus. Dalam pelaksanaan siklus I dilakukan sebanyak 4 kali pertemuan yang diakhiri dengan pelaksanaan tes. Pada pertemuan pertama sampai ketiga membahas materi pelajaran dan kerja kelompok, sedangkan pertemuan keempat dilakukan tes akhir siklus I, pemberian penghargaan dan hadiah bagi kelompok tim yang mendapatkan nilai tertinggi. Demikian pula pada pelaksanaan siklus II yang terdiri dari 4 pertemuan.

Proses pembelajaran yang dilakukan dengan model pembelajaran Student Teams Achievement Divisions terbagi pada tiga kegiatan yaitu kegiatan awal, inti, dan akhir.

Pada kegiatan awal, peneliti melakukan kegiatan sehari-hari mulai mengucapkan salam, mengabsensi siswa, melakukan apersepsi dan menyampaikan tujuan atau kompetensi dasar pembelajaran.

Pada kegiatan inti, peneliti menjelaskan materi dengan metode ceramah dan demonstrasi, kemudian menyuruh siswa untuk bergabung dengan kelompoknya yang sudah ditentukan sebelumnya. Peneliti membagikan lembar kerja kelompok kepada masing-masing kelompok. Lembar kerja tersebut harus diselesaikan secara kelompok dengan maksud mengajak siswa untuk berfikir kritis serta menuntut siswa untuk bertanggung jawab atas anggota kelompoknya apabila ada teman sekelompoknya yang belum mengerti tentang materi yang dibahas sebelum bertanya kepada peneliti. Setelah selesai diskusi, peneliti memberi kesempatan untuk setiap kelompok secara bergantian mempresentasikan hasil kerja mereka dan kelompok lain menanggapinya.

Pada kegiatan akhir setelah presentasi selesai, kegiatan dilanjutkan dengan mengerjakan tes akhir siklus kemudian guru/peneliti mengevaluasi hasil belajar siswa. Guru memberikan bintang penghargaan kepada kelompok yang mendapat nilai tertinggi kemudian melakukan refleksi. Kegiatan diakhiri dengan salam tetapi sebelumnya siswa diberikan pesan-pesan akademik dan kembali ke tempat duduk masing-masing. Soal kuis diberikan untuk menentukan siswa yang boleh pulang terlebih dahulu.

Dalam pelaksanaan penelitian ini, peneliti dibantu oleh 2 observer (teman sejawat) yang bertugas untuk mengamati dan mendokumentasikan aktivitas peneliti dan siswa selama proses pembelajaran berlangsung dengan 
menggunakan format observasi yang telah disiapkan oleh peneliti guna menganalisis data dan merencanakan siklus selanjutnya.

Hasil belajar siswa setelah memperoleh pengalaman belajar dengan model pembelajaran Student Teams Achievement Division mengalami peningkatan. Gambaran peningkatan itu dapat dilihat dari perlakuan tes awal, tes siklus I, dan tes siklus II.

Sebelum dilakukan penerapan model pembelajaran Student Team Achievment Devision, peneliti melakukan tes awal. Rata-rata nilai tes awal pada siswa SMK Negeri 1 Parepare diperoleh sebanyak 70,40; tes akhir siklus I 85,80; dan tes akhir siklus II 96,60.

Pada pelaksanaan tes awal diperoleh hasil penelitian pada tingkat pencapaian ketuntasan siswa dalam proses pembelajaran sebanyak 3 orang siswa yang tuntas dan sebanyak 22 orang siswa yang tidak tuntas. Hal ini menunjukkan bahwa Kriteri Ketuntasan Minimal yang ditentukan sekolah belum tercapai. Dengan demikian, peneliti memutuskan untuk melakukan eksperimen dalam bentuk penelitian tindakan kelas dengan menggunakan model pembelajaran Student Team Achievment Devision.

Setelah melakukan eksperimen penelitian tindakan kelas pada siklus I, peneliti menemukan hasil penelitian dengan tingkat ketuntasan sebanyak 3 atau $22 \%$ orang siswa yang tergolong tidak tuntas dan 22 atau $88 \%$ orang siswa yang tuntas. Hal ini menunjukkan terjadinya kebalikan hasil penelitian yang dilakukan pada tes awal. Namun demikian, peneliti dan observer memutuskan untuk tetap melanjutkan pembelajaran ke tahap siklus selanjutnya sampai pada pencapaian perolehan tingkat ketuntasan 100\%.

Setelah melakukan eksperimen penelitian tindakan kelas pada siklus II, peneliti menemukan hasil penelitian dengan tingkat ketuntasan sebanyak 25 atau $100 \%$ orang siswa yang tergolong kategori tuntas dan tidak terdapat siswa yang tidak tuntas. Hal ini menunjukkan terjadinya hasil penelitian yang sangat signifikan baik pada nilai rata-rata siswa maupun tingkat ketuntasannya jika dibandingkan dengan perolehan nilai pada tes awal. Dengan demikian, peneliti dan observer memutuskan untuk tidak melanjutkan pembelajaran ke tahap siklus selanjutnya karena perolehan nilai rata-rata dan tingkat ketuntasannya sudah mencapai titik yang maksimal yaitu $100 \%$.

Penerapan model pembelajaran Student Teams Achievement Divisions ini efektif dapat meningkatkan pemahaman dan hasil belajar siswa dalam mempelajari Pendidikan Agama Islam pada materi Alquran sebagai Pedoman hidup: Iman Kepada Kitab-kitab Allah swt. dan Kepedulian Umat Islam terhadap Jenazah di SMK Negeri 1 Parepare. 


\section{SIMPULAN}

Model pembelajaran Student Teams Achievement Divisions memiliki dampak positif terhadap kerjasama antar siswa karena tidak membeda-bedakan dengan yang lain. Hal tersebut ditunjukkan dari tanggung jawab siswa dalam kelompok; siswa yang lebih menguasai materi mengajari temannya yang kurang mampu. Dalam proses pembelajaran dengan menggunakan model pembelajaran Student Teams Achievement Divisions yang dilakukan secara bersiklus, keaktifan siswa mengalami peningkatan yang lebih baik dibandingkan menggunakan metode ceramah. Selain itu hasil belajar Pendidikan Agama Islam siswa mengalami peningkatan setelah menggunakan model pembelajaran Student Teams Achievement Divisions. Hal ini dapat ditunjukkan dari nilai rata-rata tes siswa, yaitu rata-rata nilai tes awal 70,4; pada siklus I nilai rata-rata tes akhir tindakan meningkat menjadi 85,80; dan pada tes akhir siklus II nilai rata-ratanya meningkat menjadi 96,60. Dengan demikian, model pembelajaran Student Teams Achievement Divisions efektif dalam meningkatkan hasil belajar siswa khususnya di kelas XI SMK Negeri 1 Parepare.

\section{REFRENCES}

(1) Buhaerah. 2009. Pengembangan Perangkat Pembelajaran Berdasarkan Masalah Pada Materi Statistika. Makasar: UNM.

(2) Cahyo, Agus N. 2013. "Panduan Aplikasi Teori-Teori Belajar Mengajar Teraktual Dan Terpopuler." Yogyakarta: Diva Press.

(3) Huda, Miftahul. 2011. “Cooperative Learning Metode, Teknik, Struktur Dan Model Penerapan." Yogyakarta: Pustaka Pelajar.

(4) Mustamin. 2009. Strategi Pembelajaran. Surabaya: Revka Petra Media.

(5) Sukardi, Ismail. 2013. “Model-Model Pembelajaran Modern." Palembang: Tunas Gemilang Press.

(6) Rahman, Abdul Saleh, Muhbib Abdul Wahab. Psikologi Suatu Pengantar Dalam Perfektif Islam. Jakarta:Kencana. 2004.

(7) Riduwan dkk. Pengantar statistika untuk penelitian pendidikan, sosial, ekonomi, komunikasi, dan bisnis. Bandung: alfabeta. 2015

(8) Rizqi, Fimel. Hadits Tentang Media Pembelajaran. diakses dari http://fimelrizqi.blogspot.co.id/2012/04/hadits-tentang-mediapembelajaran.html, pada tanggal 28 september 2016.

(9) Sanjaya, Wina. Perencanaan dan Desain Sistem Pembelajaran. Jakarta: Kencana Prenada Media Group. 2010.

(10) Santrock, John W.Psikologi Pendidikan. Jakarta: PT Fajar Interpratama Offset. 2010.

(11) Sukardi. Metodologi Penelitian Pendidikan Kompetensi Dan Praktiknya. Jakarta: PT Bumi Aksara. 2010.

(12) Trianto, M Pd, and M Pd. 2009. "Mendesain Model Pembelajaran Inovatif-Progresif." Jakarta: Kencana. 